\title{
Peran Mesenchymal Stem Cells dalam Regulasi PDGF dan Sel Islet pada Diabetes
}

\section{The Role of Mesenchymal Stem Cells on Regulating PDGF and Islet Cells in Diabetes}

\author{
Zakariya $\mathrm{HS}^{1}$, Agung Putra ${ }^{2}$ \\ ${ }^{1}$ Mahasiswa Pascasarjana Biomedik Fakultas Kedokteran Universitas Islam Sultan Agung Semarang \\ ${ }^{2}$ Stem Cell and Cancer Research Institute Fakultas Kedokteran Universitas Islam Sultan Agung Semarang
}

\begin{abstract}
ABSTRAK
Diabetes merupakan kelompok penyakit metabolik yang ditandai dengan peningkatan kadar glukosa darah sebagai akibat kerusakan sel $\beta$ pankreas dan atau resistensi insulin. Penelitian klinik menunjukan bahwa transplantasi islet dapat memperbaiki gejala terkait diabetes, meskipun demikian keterbatasan pendonor menjadi masalah serius. Hasil penelitian terkini melaporkan bahwa Mesenchymal Stem Cells (MSCs) berpotensi tinggi dalam meregenerasi kerusakan jaringan pankreas termasuk sel islet dengan melibatkan berbagai growth factor terutama PDGF. Tujuan penelitian ini adalah untuk mengetahui pengaruh MSCs tali pusat dalam meningkatkan jumlah sel islet dan gambaran kadar PDGF pada hari ke 44 fase remodelling jaringan pankreas yang rusak. Penelitian ini menggunakan 20 mencit (Mus musculus) Balb-C yang diinduksi streptozotocin hingga diabetes. Terdapat 4 kelompok penelitian ( $n=5 /$ kelompok) terdiri atas kontrol (K) dan perlakuan ( $P$ ). Kelompok kontrol diberi PBS sementara P1, P2, dan P3 diberi MSCs dengan dosis berbeda, yaitu: $\mathrm{P} 1=1,5 \times 10^{5}, \mathrm{P} 2=3 \times 10^{5}$, dan $P 3=6 \times 10^{5}$ sel secara intraperitoneal. Pada hari ke 44 dilakukan pemeriksaan ELISA pada sampel darah untuk mengetahui kadar PDGF dan histopatologi jaringan untuk penghitungan sel islet pankreas. Hasil penelitian didapatkan peningkatan jumlah sel islet pankreas secara signifikan $(p<0,05)$ dan kadar PDGF sesuai dengan kelompok kontrol. Penelitian eksperimental pada mencit (Mus musculus) inimengesankan bahwa MSCs mampu meningkatkan jumlah sel islet pankreas dan meregulasi kadar PDGF.
\end{abstract}

Kata Kunci: Diabetes, jumlah sel islet, kadar PDGF, MSCs

\begin{abstract}
ABSTRACK
Diabetes is a group of metabolic disease characterized by increased level of blood glucose as a result of defect in $B$ Cells destruction and or insulin resistance. Clinical studies showed that transplantation of islet is sufficient cure to relieffrom the diabetes-related symptom. However, the lack of applicable donor is becoming a serious problem. Recent study has shown that Mesenchymal Stem Cells (MSCs) has high-potential to regenerate pancreatic tissue damage including islet Cells by involving various growth factors such as PDGF. The aim of this study is to determine the effect of umbilical cord MSCs in increasing the number of islet Cells and PDGF level appearance on the 44th day of remodeling phase in pancreatic tissue damage. This study used 20 streptozotocin-induced balb-c mice (Mus musculus) to diabetes divided into four group ( $n=5$ /group) consisting control $(K)$ and treatment $(P)$. The control group was treated $P B S$ while $P 1, P 2$, and $P 3$ treated different MSCs dose intraperitoneally ( $P 1=1.5 \times 10^{5}, P 2=3 \times 10^{5}$, dan $P 3=6 \times 10^{5}$ Cells). Day 44, ELISA essay were performed using blood samples to identify PDGF level apearance and tissue histopathology for counting pancreatic islet Cells. The result of this study presented the increased of islet sells significantly $(p<0.05)$ and PDGF level appearance similar to the control. Here, our experimental in model of diabetic-induced balb-c mice (Mus musculus) suggested that MSCs is able to increase the number of islet cells and regulated PDGFlevel.
\end{abstract}

Keyword: Diabetes, islet cells, MSCs, PDGFlevel

Korespondensi: Agung Putra. Stem Cell and Cancer Research (SCCR) Laboratory Fakultas Kedokteran Universitas Islam Sultan Agung. Jl. Raya Kaligawe KM. 4 Semarang, Jawa Tengah 50112 Tel. 08164251646 Email: dr.agungptr@gmail.com

DOI: http://dx.doi.org/10.21776/ub.jkb.2018.030.02.4 


\section{PENDAHULUAN}

Diabetes adalah kelompok sindroma metabolik yang ditandai dengan hiperglikemia meliputi gangguan metabolik karbohidrat, lemak dan protein sebagai akibat defisiensi sekresi insulin dan atau gangguan kerja insulin (1). Secara umum diabetes dibagi 2 yaitu tipe 1 dan tipe 2. Diabetes tipe 1 disebabkan oleh kerusakkan sel $\beta$ pankreas akibat proses autoimun, sedangkan diabetes tipe 2 merupakan kombinasi faktor genetik dan non genetik yang berakibat pada resistensi insulin dan defisiensi insulin (1). Federasi Diabetes Internasional melaporkan bahwa terdapat 415 juta jiwa penderita Diabetes Melitus (DM) dengan prevalensi 9,1\% pada 2015 dan akan menjadi $10 \%$ pada tahun 2040 (2). Transplantasi sel $\beta$ pankreas menunjukan pencapaian hasil yang baik dalam penanganan diabetes, namun keterbatasan pendonor dan potensi penolakan oleh sel imun menjadi kendala (3), sementara suntik insulin beresiko ketergantungan jangka panjang, kesulitan penyesuaian jumlah insulin eksogen dan potensi terjadi resistensi insulin (4). Mesenchymal Stem Cells (MSCs) dapat berdiferensiasi menjadi berbagai macam sel termasuk sel penghasil insulin (5), sehingga mampu meregenerasi sel $\beta$ pankreas dan memperbaiki resistensi insulin pada penderita DM (6).

Mesenchymal stem cells (MSCs) merupakan sel punca dewasa yang berasal dari jaringan stromal dengan karakteristik mampu mengekspresikan berbagai surface marker berupa CD73, CD90 dan CD105 serta sedikit mengekspresikan CD45, CD34, CD14 atau CD11 CD79/CD19, dan HLA-DR (7). Mesenchymal stem cells (MSCs) diperoleh dari berbagai jaringan seperti sumsum tulang belakang, adiposa, placenta, dan tali pusat (8). Mesenchymal stem cells (MSCs) asal tali pusat diduga memiliki potensi stemness yang lebih kuat dibanding dengan asal sumsum tulang, selain itu teknik pengambilan MSCs asal tali pusat relatif lebih mudah dan non invasif. Mesenchymal stem cells (MSCs) mampu memperbaharui diri sendiri (self renewal) dan berdiferensiasi menjadi sel spesifik (multilineage differentiation) termasuk menjadi sel $\beta$ pankreas (9). Sisi lain, MSCs juga berkemampuan mensekresi berbagai molekul bioaktif secara parakrin seperti vascular endothelium growth factor (VEGF) dan platelet-derived growth factor (PDGF) yang berperan kuat dalam peningkatan regenerasi vaskuler, angiogenesis dan pengurangan jumlah sel apoptosis (3). Ketika terjadi luka, molekul pro-inflamasi seperti TNF- $\alpha$ akan mengaktivasi MSCs untuk melepaskan beberapa growth factor $(10,11)$. Kadar growth factor terutama PDGF umumnya digunakan sebagai indikator pertumbuhan sel islet pankreas (12).

Platelet-Derived Growth Factor (PDGF) berperan sebagai salah satu faktor pertumbuhan dan pembelahan sel khususnya saat fase angiogenesis dan pembentukan pembuluh darah dari jaringan pembuluh darah sebelumnya (12,13). Platelet-Derived Growth Factor (PDGF) akan mengirim sinyal yang mampu memicu migrasi berbagai tipe sel saat inflamasi disamping menginduksi proliferasi seluler. Kadar PDGF mengalami peningkatan pada minggu awal dengan tujuan mendorong proses neovaskularisasi dan mengalami penurunan secara perlahan sejalan dengan fase penyembuhan luka (14). Penelitian ini bertujuan untuk mengatahui pengaruh MSCs tali pusat terhadap peningkatan jumlah sel islet pankreas fase remodeling yang disertai dengan penurunan kadar PDGF.

\section{METODE}

Induksi Diabetes Eksperimental
Mencit (Mus musculus) galur Balb-C jantan berumur 10 minggu diinjeksi $40 \mathrm{mg} / \mathrm{kg}$ streptozotocin (STZ; SigmaAldrich, S0130) secara intraperitoneal selama 5 hari berturut-turut hingga diabetes. STZ dilarutkan dalam larutan sodium sitrat, $\mathrm{pH} 4,5$. Seluruh prosedur sudah sesuai dengan ketentuan komisi etik ekperimental Fakultas Kedokteran Universitas Sultan Agung (Unissula). Prosedur pembuatan tikus model berdasarkan protokol standar untuk memperoleh model hewan coba diabetes. Protokol mengacu pada buku seri protokol penelitian hewan coba Kelompok Kajian Animal Modelling Departemen Ilmu Faal FKUNAIR.

\section{Isolasi MSCS}

Tali pusat tikus (Rattus norvegicus) betina hamil 19 hari dibersihkan dengan larutan PBS. Pembuluh darah tali pusat dibuang kemudian tali pusat dipotong dengan pisau steril sepanjang 2-5 $\mathrm{mm}$ dan diletakkan secara merata dalam cawan kultur $66 \mathrm{~mm}$. Medium yang digunakan adalah medium kultur DMEM (Sigma-Aldrich, Louis St, MO, MFCD00217342) dicampur dengan 10\% FBS, 100IU/ml penicilin/streptomicin (GIBCO, Invitrogen, 15140122) kemudian diinkubasi pada suhu $37^{\circ} \mathrm{C}$ dengan $5 \% \mathrm{CO}_{2}$. Penggantian medium dilakukan setiap 3 hari sekali. Setelah 4-5 kali pasase, sel dikultur 8-10 hari hingga konfluen $80 \%$ kemudian dilakukan pemanenan dengan cara pemberian 0,25\% tripsin-EDTA (catalog number: 25200056) pada suhu $37^{\circ} \mathrm{C}$. Sel yang digunakan dalam penelitian ini adalah sel hasil pasase ke 5 .

\section{Karakteristik Fenotip MSCs}

Ekspresi MSCs hasil isolasi dinilai dengan teknik immunocytochemistry yang ditunjukan dengan ekspresi CD 73 dan CD 105 (marker MSCs). Setelah MSCs konfluen 6080\% (3-4 minggu), MSCs dipanen dan ditumbuhkan di coverslips dengan kerapatan $5 \times 10^{3}-1 \times 10^{4}$ sel selama 3-4 hari kemudian di fiksasi dengan $4 \%$ paraformaldehyde dalam $90 \%$ ethanol selama 15 menit dan suhu $4^{\circ} \mathrm{C}$. Sel diinkubasi dengan antibodi primer CD 73 dan CD 105 yang merupakan penanda karakter MSCs (1:100) ( BD Pharmingan, San diego. CA USA, no: 563198, 561443) selama 60 menit dalam suhu ruang. Marker tersebut merupakan kriteria minimal yang harus digunakan dalam uji fenotip MSCs sesuai dengan ketentuan The International Society for Cellular Theraupy (15). CD 105 merupakan glikoprotein membran tipe 1 yang berfungsi sebagai asesory reseptor TGF-b yang merupakan molekul faktor stemness (16). Sisi lain CD 73 memiliki peran khusus dalam meregulasi proses inflamasi jaringan cidera (17). Sel kemudian dicuci dengan PBS selama 10 menit kemudian ditambahkan antibodi kedua (1;2500 dilution) selama 15 menit dalam suhu ruang kemudian dilakukan counterstaining dengan 3,3'Diaminobenzidine (DAB) (Santa Cruz Biotech, SC-24982) dan diamati dengan mikroskop (18).

\section{Diferensiasi In Vitro}

MSCs ditanam dalam cawan kultur dengan kerapatan $5 \times 10^{3}-$ $1 \times 10^{4} \mathrm{sel} /$ sumuran diberi perlakuan medium induksi osteogenik yang berisi $10 \mathrm{mmol} / \mathrm{L}$ b-glycerophosphate, $0,1 \mu \mathrm{mol} / \mathrm{L}$ dexamethasone, $50 \mu \mathrm{mol} / \mathrm{L}$ ascorbate-2phosphate (Sigma-Aldrich, Louis St, MO, MFCD00064136) dan $10 \%$ FBS dari total volume medium dalam DMEM. Diferensiasi osteogenik diamati dengan pewarnaan Alazarin Red setelah 21 hari induksi untuk mengetahui deposit kalsium. Sel dibilas dengan PBS dan difiksasi dengan etanol dingin $70 \%(\mathrm{v} / \mathrm{v})$ selama 1 jam dalam suhu ruang kemudian dibilas tiga kali dengan aquabides. Larutan Alizarin Red sebanyak $1 \mathrm{ml}$ dari $2 \%(\mathrm{w} / \mathrm{v})(\mathrm{pH} 4,1-4,3)$ ditambahkan dan diinkubasi selama 30 menit dalam suhu ruang kemudian 
dibilas empat kali dengan aquabides. Diferensiasi in vitro MSCs menjadi sel adiposit dianggap sudah mewakili kemampuan MSCs dalam berdiferensiasi (19).

\section{Transplantasi MSCs dan Pemantauan Fisiologi}

Mencit (Mus musculus) model diabetes ( $n=5 /$ kelompok), disuntik secara intraperitoneal dengan dosis berbeda. Kelompok kontrol diberikan penyuntikan (Phospat Buffer Saline) PBS. Kelompok P1, P2, dan P3 disuntik MSCs dengan dosis $1,5 \times 10^{5}, 3 \times 10^{5}$ dan $6 \times 10^{5}$ sel dalam $0,5 \mathrm{cc}$ PBS secara intraperitoneal. Setelah 44 hari perlakuan, sampel darah tikus diambil melalui vena orbita lalu dikorbankan secara dislokasi cervical kemudian dilakukan pengambilan jaringan pankreas untuk pembuatan sediaan preparat.

\section{Pengujian Human PDGFELISA}

Uji kadar PDGF serum dengan ELISA kit (Fine test ER1240, China) dilakukan sesuai petunjuk penggunaan pada suhu ruang. Plate ELISA dilapisi dengan capture antibody dan diinkubasi semalam pada suhu $4^{\circ} \mathrm{C}$. Sumuran dicuci kemudian diblok selama 1 jam. Sumuran diinkubasi dengan larutan standar PDGF tikus, serum darah tikus perlakuan dan kontrol selama 2 jam, dicairkan dengan perbandingan 1:100 hingga didapatkan pengukuran dalam kurva standar. Setelah pencucian, sumuran diinkubasi dengan antibodi deteksi selama satu jam, kemudian dicuci kembali beberapa kali. Sumuran diinkubasi dengan Avidin-HRP selama 30 menit, dicuci bersih, diinkubasi dengan substrat solution selama 15 menit, diikuti dengan penambahan stop solution, dan hasil $\mathrm{A}_{450}$ diukur dengan microplate reader.

\section{Analisis Histologi}

Setelah jaringan pankreas diperoleh, dimasukan dalam $10 \%$ neutral-buffered formalin kemudian ditanamkan dalam parafin atau Histogel (Thermo Scientific HG-4000012, Watham, MA, USA). Jaringan yang sudah menempel dengan parafin kemudian dipotong menggunakan mikrotom dengan ketebalan 5-10 $\mu$ m kemudian diwarnai dengan Hematoksilin Eosin (HE) Ialu diamati menggunakan mikroskop cahaya.

\section{Analisis Data}

Analisis data di lakukan dengan metode statistik KruskalWallis Test yang dilanjutkan dengan Mann-Whitney Test serta uji korelasi dengan Spearman Test.

\section{HASIL}

\section{Karakteristik MSCs}

Identifikasi karakteristik MSCs dilakukan dengan marker CD 73 dan CD 105 dengan immunocytocemistry (Gambar 1).
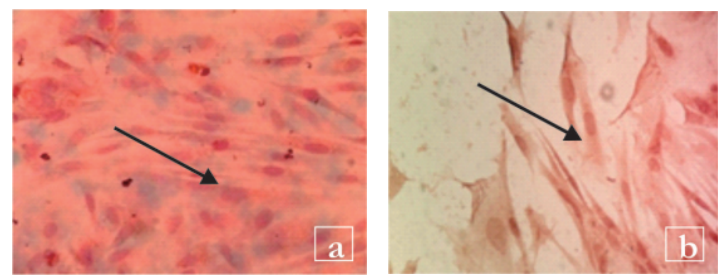

Gambar 1. Karakteristik mesenchimal stem cells hasil kultur pembesaran 100x

Keterangan: Morfologi MSCs berbentuk spindel seperti sel fibroblas ditandai dengan warna coklat yang ditunjuk anak panah (a) ekspresi CD 105, (b) ekspresi CD 73 MSCs
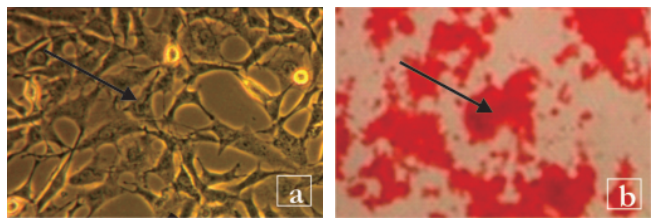

Gambar 2. Kandidat MSCs asal tali pusat dan uji diferensiasi mesenchymal stem cells

Keterangan: (a) kandidat MSCs tampak sel berbentuk spindel seperti fibroblas ditunjukan anak panah (b) Deposit kalsium pada sel osteogenik tampak berwarna merah ditunjukan dengan panah (hasil diferensiasi MSCS).

Uji diferensiasi osteogenik MSCs dilakukan secara in vitro dalam sumuran. Identifikasi deposit kalsium menggunakan Alazarin red (Gambar 2).

KadarPDGF

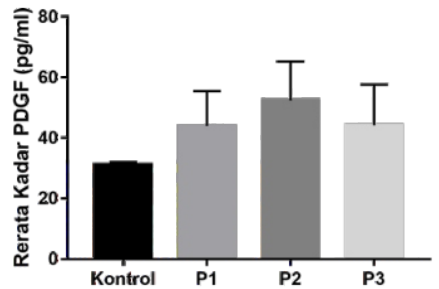

\section{Gambar 3. Rerata kadar PDGF hari ke 44}

Keterangan: Tidak terdapat perbedaan signifikan kadar PDGF hari ke 44 antara kelompok kontrol dengan semua perlakuan

Pengukuran kadar PDGF dilakukan 44 hari pasca induksi MSCs. Prosedur pelaksanaan dilakukan sesuai protokol pabrik yang berlaku. Hasil menunjukan tidak terdapat perbedaan yang signifikan $(P>0,05)$ antara kontrol dengan perlakuan. Kadar PDGF kelompok P1: $44,04 \pm 1,14 \mathrm{pg} / \mathrm{ml}$, P2: $52,46 \pm 1,28 \mathrm{pg} / \mathrm{ml}$, dan P3: $44,26 \pm 1,34 \mathrm{pg} / \mathrm{ml}$ serta kontrol 31,17 $\pm 0,82 \mathrm{pg} / \mathrm{ml}$ (Gambar 3).

Jumlah Sel Islet Pankreas

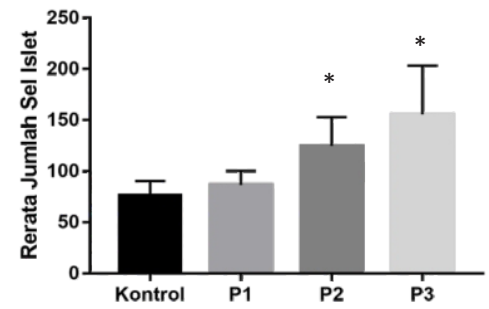

Gambar 4. Rerata jumlah sel islet pankreas hari ke 44

Keterangan: Terdapat perbedaan signifikan jumlah sel islet hari ke 44 antara kelompok kontrol dengan perlakuan, *: terdapat perbedaan signifikan

Penghitungan jumlah sel islet pankreas dilakukan di laboratorium Patologi Anatomi Rumah Sakit Islam Sultan Agung. Terdapat perbedaan yang signifikan $(p<0,05)$ 
jumlah sel islet pada hari ke-44. Gambar 4 menunjukkan jumlah sel islet pankreas pada kelompok P3 yaitu $155,60 \pm 47,57$ sel, $P 2$ yaitu $124,60 \pm 28,11$ sel dan $P 1$ yaitu $86,40 \pm 13,89$ sel sedangkan kontrol $76,00 \pm 14,27$ sel.
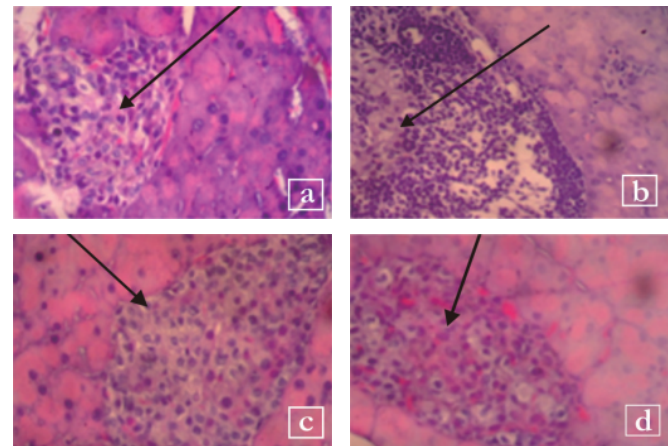

Gambar 5. Gambaran sel islet pada hari ke 44 setelah perlakuan

Keterangan: (a) kelompok kontrol (b), (c), (d) kelompok P1, P2, dan P3 (panah hitam menunjukan pulau islet)

Pada hari ke 44 (Gambar 5) sel islet kelompok kontrol menunjukkan pulau islet yang lebih kecil dibandingkan perlakuan.

\section{DISKUSI}

Pertumbuhan jaringan pankreas ditentukan oleh proses diferensiasi stem cells/progenitor (neogenesis) menjadi sel islet disamping proliferasi sel islet itu sendiri (19). Proses diferensiasi tersebut juga dipengaruhi oleh respon luka (20). Diferensiasi terjadi ketika MSCs migrasi ke area luka akibat pelepasan molekul tetentu, diantaranya haematopoietic Cells E-/L-selectin ligand (HCELLS), matrix metalloproteinases (MMP) dan SDF-1 (21). Molekul ini mampu menarik MSCs masuk dalam pembuluh darah yang kemudian diikuti transmigrasi ke luar endotelium (22).

Hasil penelitian ini menunjukan bahwa pemberian serial dosis MSCs tali pusat tikus dapat meningkatkan jumlah sel islet pankreas. Hal ini sesuai dengan penelitian sebelumnya yang melaporkan bahwa pemberian human Mesenchymal Stem Cells (hMSCs) pada tikus model mampu meningkatkan sel $\beta$ pankreas dan produksi insulin (23). Terdapat perbedaan signifikan antara kelompok kontrol dengan perlakuan pasca pemberian serial dosis MSCs yang menunjukkan peningkatan jumlah sel islet sesuai dengan pemberian dosis MSCs. Hal ini dapat dilihat pada gambaran mikroskopik jumlah sel islet preparat jaringan pankreas. Mekanisme regenerasi MSCs pada daerah luka diduga melalui proses diferensiasi, vaskularisasi dengan melibatkan pelepasan berbagai molekul parakrin diantaranya PDGF.

\section{DAFTAR PUSTAKA}

1. American Diabetes Association. Diagnosis and Classification of Diabetes Mellitus. Diabetes Care. 2010; 33(1): 62-69.

2. Shaw JE, Sicree RA, and Zimmet PZ. Global Estimates of the Prevalence of Diabetes for 2010 and 2030. Diabetes Research and Clinical Practice. 2010; 87(1):
Penelitian ini juga mendapatkan kadar PDGF yang tidak berbeda signifikan pada hari ke 44 antara kelompok kontrol dan perlakuan. Diduga telah terjadi penurunan kadar PDGF seiring dengan peningkatan jumlah sel islet secara signifikan. Hal ini menunjukan bahwa proses reparasi jaringan rusak telah memasuki fase remodeling. Fakta ini sesuai dengan penelitian sebelumnya yang melaporkan bahwa PDGF mengalami kenaikan signifikan pada fase proliferasi yaitu hari ke 7 dan 14 paska inflamasi (24), disebabkan PDGF dibutuhkan berbagai sel dalam melakukan proses proliferasi dan regenerasi. Kadar PDGF akan menurun secara perlahan seiring dengan proses penyembuhan memasuki fase remodeling. Kadar PDGF yang tetap tinggi pada fase remodeling menunjukan bahwa terjadi aktivasi sel fibroblas secara terus menerus yang berdampak pada fibrosis jaringan (25). Hal tersebut menunjukan bahwa proses perbaikan jaringan secara sempurna tidak terjadi.

Aktivasi fibroblas terjadi melalui extracellular signalregulated kinase (ERK1/2), yang merupakan salah satu komponen MAPK dalam meningkatkan ekspresi c-fos protein yang berperan sentral pada regenerasi jaringan (26). Peran penting MSCs dalam penelitian ini kami duga melalui parakrinisasi dengan mensekresikan berbagai molekul bioaktif terutama PDGF untuk mengaktivasi berbagai sel sekitar termasuk sel punca endogenous disamping melakukan proses diferensiasi menjadi sel islet sehingga proses regenerasi terjadi secara optimal. Saat sel islet mulai terbentuk, PDGF akan mengalami penurunan sehingga dapat memberikan informasi tentang laju pertumbuhan sel pankreas. Hal ini sejalan dengan hasil penelitian kami, bahwa kadar PDGF pada semua perlakuan tidak berbeda nyata yang mengindikasikan terjadi penurunan kadar PDGF pada hari ke 44 fase remodeling seiring dengan pertumbuhan sel islet yang telah mencapai optimum. Hasil ini mengesankan bahwa MSCs berperan sentral dalam berbagai fase penyembuhan jaringan. MSCs dapat memperbaiki kerusakan sel islet pada mencit (Mus musculus) hiperglikemia yang diinduksi STZ secara aman. Kadar PDGF yang diukur pada fase remodeling (hari ke 44) tidak signifikan karena proses penyembuhan luka sudah selesai. Pada penelitian ini kami tidak melakukan analisis pada sel $\beta$ pankreas, sehingga tidak diketahui secara pasti peran MSCs dalam diferensiasi menjadi sel $\beta$ pankreas.

Penelitian ini membuktikan bahwa pemberian serial dosis MSCs tali pusat tikus dapat menaikkan jumlah sel islet pankreas. Tidak ada perbedaan pada kadar PDGF karena telah memasuki fase remodeling.

\section{UCAPAN TERIMAKASIH}

Ucapan terimakasih kami sampaikan kepada laboratorium Stem Cells and Cancer Research (SCCR) FK Unissula beserta staf dan Prodi S2 Biomedik FK Unissula atas izin dan fasilitas pendukung dalam penelitian ini.

\section{4-14.}

3. Montanari E, Meier RPH, Mahou R, et al. Multipotent Mesenchymal Stromal Cells Enhance Insulin Secretion From Human Islets Via N-Cadherin Interaction and Prolong Function of Transplanted Encapsulated Islets In Mice. Stem Cell Research \& Therapy. 2017; 8(1): 199-210. 
4. Dang LT, Phan NK, Truong KD. Mesenchymal Stem Cells for Diabetes Mellitus Treatment: New Advances. Biomedical Research and Therapy. 2017; 4(1): 1062-1081.

5. Wang $\mathrm{H}$, Qiu $\mathrm{X}, \mathrm{Ni} \mathrm{P}$, et al. Immunological Characteristics of Human Umbilical Cord Mesenchymal Stem Cells and the Therapeutic Efects of Their Transplantion on Hyperglycemia in Diabetic Rats. International Journal of Molecular Medicine. 2014; 33(2): 263-270.

6. Zang L, Hao H, Liu J, Li Y, Han W, and Mu Y. Mesenchymal Stem Cell Therapy in Type 2 Diabetes Mellitus. Diabetology \& Metabolic Syndrome. 2017; 9: 36-46.

7. Semenov OV, Koestenbauer S, Riegel $\mathrm{M}$, et al. Multipotent Mesenchymal Stem Cells from Human Placenta: Critical Parameters for Isolation and Maintenance of Stemness after Isolation. American Journal of Obstetrics and Gynecology. 2010; 202(2): 193.e1-193.e13.

8. Ringe J, Leinhase I, Stich S, et al. Human Mastoid Periosteum-Derived Stem Cells: Promising Candidates for Skeletal Tissue Engineering. Journal of Tissue Engineering and Regenerative Medicine. 2008; 2(2-3): 136-146.

9. Sharma A and Rani R. Do We Really Need to Differentiate Mesenchymal Stem Cells Into InsulinProducing Cells for Attenuation of the Autoimmune Responses in Type 1 Diabetes: Immunoprophylactic Effects of Precursors to Insulin-Producing Cells. Stem Cell Research \& Therapy. 2017; 8: 167-181.

10. Endang T dan Sukma D. Ekstrak Metanol Daun Kelor Menurunkan Kadar TNF- $\alpha$ dan IL-6 Serum, serta MDA Kolon Tikus yang Diinduksi DMBA. Jurnal Kedokteran Brawijaya. 2016; 29(1): 25-31.

11. Crisostomo PR, Wang Y, Markel TA, Wang M, Lahm T, and Meldrum DR. Human Mesenchymal Stem Cells Stimulated By TNF- , LPS, Or Hypoxia Produce Growth Factors By An NF B-But Not JNK-Dependent Mechanism. American Journal of Physiology. Cell Physiology. 2008; 294(3): 675-682.

12. Chen $\mathrm{H}, \mathrm{Gu} X$, Liu Y, et al. PDGF Signalling Controls Age-Dependent Proliferation In Pancreatic B-Cells. Nature. 2011; 478(7369): 349-355.

13. Raica M and Cimpean AM. Platelet-Derived Growth Factor (PDGF)/PDGF Receptors (PDGFR) Axis As Target For Antitumor and Antiangiogenic Therapy. Pharmaceuticals. 2010; 3(3): 572-599.

14. Nair DG, Miller KG, Lourenssen SR, Blennerhassett MG. Inflammatory Cytokines Promote Growth of Intestinal Smooth Muscle Cells by Induced Expression of PDGF-R?? Journal of Cellular and Molecular Medicine. 2014; 18(3): 444-454.

15. Dominici M, LeBlanc K, Mueller I, et al. Minimal Criteria For Defining Multipotent Mesenchymal
Stromal Cells. The International Society for Cellular Therapy position Statement. Cytotherapy. 2006; 8(4): 315-317.

16. Nassiri F, Cusimano MD, Scheithauer BW, et al. Endoglin (CD105): A Review of its Role in Angiogenesis and Tumor Diagnosis, Progression and Therapy. Anticancer Research. 2011; 31(6): 22832290.

17. Monguió-Tortajada M, Roura S, Gálvez-Montón C, Franquesa $M$, Bayes-Genis $A$, and Borràs FE. Mesenchymal Stem Cells Induce Expression of Cd73 in Human Monocytes In Vitro and in a Swine Model of Myocardial Infarction In Vivo. Frontiers in Immunology 2017; 8: 1577-13.

18. Putra A, Sa'diyah NAC, Rahmalita A, Tarra $Y$, Prihananti DH, Hutama SH. The Effect of Mesenchymal Stem Cells on the Endothelial Cells of Diabetic Mice. Proceedings of the International Conference on the 4th Bibmc (Bandung International Biomolecular Medicine Conference) 2016 and the 2nd Acmm (ASEAN Congress on Medical Biotechnology and Molecular Biosciences). Bandung, October 4-6, 2016; hal. 57-60.

19. He D, Wang J, Gao Y, and Zhang Y. Differentiation of PDX1 Gene-Modified Human Umbilical Cord Mesenchymal Stem Cells Into Insulin-Producing Cells In Vitro. International Journal of Molecular Medicine. 2011; 28(6): 1019-1024.

20. Bonner-Weir S, Guo L, Li WC, et al. Islet Neogenesis: A Possible Pathway for Beta-Cell Replenishment. The Review of Diabetic Studies. 2012; 9(4): 407-416.

21. Becker A De and Riet IV. Homing and Migration of Mesenchymal Stromal Cells: How To Improve the Efficacy of Cell Therapy? World Journal of Stem Cells. 2016; 8(3): 73-87.

22. Karp JM and Leng Teo GS. Review Mesenchymal Stem Cell Homing: The Devil Is in the Details. Cell Stem Cell. 2009; 4(3): 206-216.

23. Lee RH, Seo MJ, Reger RL, et al. Multipotent Stromal Cells From Human Marrow Home to and Promote Repair of Pancreatic Islets and Renal Glomeruli in Diabetic NOD/Scid Mice. Proceedings of the National Academy of Sciences of the United States of America. 2006; 103(46): 17438-17443.

24. Cheng B, Liu HW, Fu XB, Sun TZ, and Sheng ZY. Recombinant Human Platelet-Derived Growth Factor Enhanced Dermal Wound Healing by a Pathway Involving ERK and C-Fos in Diabetic Rats. Journal of Dermatological Science. 2007; 45(3): 193-201.

25. Trojanowska M. Role of PDGF In Fibrotic Diseases and Systemic Sclerosis. Rheumatology. 2009; 47(5): 4-6.

26. Choi JW, Kim S, Kim TM, et al. Basic Fibroblast Growth Factor Activates MEK/ERK Cell Signaling Pathway and Stimulates the Proliferation of Chicken Primordial Germ Cells. PLoS One. 2010; 5(9): e12968. 